\title{
Building a Lifelong Education System to Promote the Popularization of Computer Education in Anshun
}

\author{
Chunhua Lu ${ }^{1, *}$, Xinhua $\mathrm{Lu}^{2}$, Fusong Chen ${ }^{3}$, Chuanhong Du ${ }^{1}$ \\ ${ }^{1}$ Department of Physics and Electronic Science, Anshun University, Anshun City, China \\ ${ }^{2}$ No.1 Middle School of Dongming County, Heze City, China \\ ${ }^{3}$ Anshun Municipal Committee Office, Anshun City, China
}

\section{Email address:}

1306038381@qq.com (Chunhua Lu),1183287401@qq.com (Xinhua Lu), 56260798@qq.com (Fusong Chen)

\section{To cite this article:}

Chunhua Lu, Xinhua Lu, Fusong Chen, Chuanhong Du. Building a Lifelong Education System to Promote the Popularization of Computer Education in Anshun. Science Discovery. Vol. 5, No. 5, 2017, pp. 327-330. doi: 10.11648/j.sd.20170505.15

Received: June 6, 2017; Accepted: July 15, 2017; Published: August 4, 2017

\begin{abstract}
With the rapid development in the era of information, computer technology has become more and more important in the development of society, and the traditional one-time computer education cannot meet the learning needs of people, while the lifelong education gradually get widely well- known. Based on the computer education status of Anshun city nowadays, this paper discusses how to construct lifelong education system from theory and practice level, therefore propose to promote lifelong education initiatives.
\end{abstract}

Keywords: Lifetime Education, Computer Education, Popularization

\section{构建终身教育体系促进安顺市计算机教育的大众化}

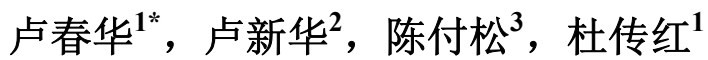

${ }^{1}$ 电子与信息工程学院, 安顺学院, 安顺市, 中国

${ }^{2}$ 东明县第一中学, 菏泽市, 中国

3 安顺市委办公室, 安顺市, 中国

邮箱

1306038381@qq.com (卢春华)，1183287401@qq.com(卢新华)，56260798@qq.com(陈付松）

摘要：随着信息时代的飞速发展，计算机技术在社会发展中占有越来越重要的地位，传统的一次性计算机教育远远不 能满足人们的学习需要, 终身教育逐渐得到人们广泛的认识。本文从安顺市的计算机教育现状出发, 论述了如何从理 论和实践层面构建终身教育体系，提出了促进终身教育的举措。

关键词：终身教育, 计算机教育, 大众化

\section{1. 引言}

随着计算机技术的飞速发展, 计算机知识更新越来越 快, 社会成员要跟上时代的步伐, 需要不断掌握计算机基 本知识, 提升计算机技能。这种学习方式的变革影响着终 身教育的发展，也为终身教育提供了广阔的空间。终身教
育最早形成于 20 世纪60年代, 并由法国著名成人教育家保 罗・朗格朗在其主要代表作《终身教育导论》中最早提出 “终身教育”概念之后，终身教育开始逐步成为世界主流的 教育思潮, 对国际教育改革产生了重要的影响[1]。中国政 府高度重视发展教育事业, 面对国际国内发展的形势, 在 1993年第一次适时地提出“终身教育”的理念, 在此思想和 
原则指导下, 构建终身教育体系日渐成为教育发展的主要 趋势。无论是从世界范围内, 还是就中国而言, 都相对较 早地开展了终身教育体系的理论研究和实践研究。安顺市 的终身教育体系建设起步较晚, 计算机教育主要以高等教 育为主, 在终身教育所覆盖的其它层次方面发展缓慢, 为 了适应社会的发展, 需要尽快补齐短板, 扩大计算机大众 化教育, 满足各行各业对计算机专业人才的需求。本文在 分析安顺市计算机教育现状的基础上, 系统地探讨构建终 身教育的途径, 以及促进安顺市计算机教育发展的措施, 以此实现人的价值, 促进当地经济和教育的发展。

\section{2. 安顺市计算机教育现状分析}

终身教育根植于教育民主化、大众化、社会化理念, 提供个人社会性学习的需要, 为学习者开启了随时、随地 学习的大门, 获得在任何环境中创造性地学习知识的机会, 有助于培养终身学习的能力。随着信息时代的电子化、智 能化、网络化的发展, 计算机已经渗透到社会生活的各个 领域, 掌握计算机技术符合终身教育的理念, 是人们学习 知识, 获得适应社会生活的一项基本技能。在终身教育思 想指导下, 安顺市面对不同群体积极开展计算机教育培训, 实施以“4L” (Learning to know, Learning to do, Learning to together, Learning to be) 为宗旨的学习模式, 以使每个人 都有机会掌握计算机技能, 从而有效运用终身学习的工具 [2]。但由于特殊的地理、历史等原因, 安顺市学习者整体 学习意识不强, 学习模式并没有被合理的运用, 再加上设 备普及问题, 导致只是少数人受计算机教育的局面, 远远 不能满足社会对计算机人才的需求。此外, 据调查统计, 2015年安顺市全日制本科院校1所，计算机科学技术专业 毕业生是 60 人; 高等职业院校 1 所, 计算机大类专业的毕 业生是399人, 安顺市广播电视大学非全日制计算机专业 毕业人数 40 人, 贵州省内外高校毕业生回安顺市报到的人 数是 12613 人, 其中计算机专业人数 600 多人 $[3]$ 。对这些数 据分析发现, 计算机专业每年毕业人数不多, 而每年各企 事业单位对计算机人才的需求与日俱增, 产生了供需矛盾。 由此看来, 在当前形势下, 为了普及计算机教育, 促进终 身教育的发展, 构建终身教育体系是拓展教育渠道的有效 途径。

\section{3. 构建终身教育体系的途径}

\section{1. 从理论研究层面构建终身教育体系}

终身教育体系的构建涉及到教育的各个层次, 社会的 各个领域, 需要全体社会成员参与的一项系统工程。就像 陈乃林先生在其《终身教育: 面向 21 世纪的教育哲学》一 文中概括的那样：要在全社会“达到人人是学习之人, 处 处是学习之所, 时时是学习之机, 事事是学习内容的境界。” 在此思想影响下, 安顺市构建终身教育体系在理论层面上 需要协调各种力量, 要求政府认真开展理论研究和经验总 结, 探索保障终身教育的功能和机制; 公众媒体大力宣传 终身教育的思想、措施及实施的意义; 各个组织或社会团 体都支持开展终身教育活动, 鼓励社会成员积极参与; 各
个社区都为民众提供接受教育的场所和设备; 社会成员主 动探索终身教育理念, 积极参与到终身教育体系的构建过 程中, 享受终身教育的成果 [4]。以上是从理论层面上构建 终身教育体系的举措, 对终身教育实践的建设起到积极指 导作用, 目的是使终身教育成为社会成员的一种自觉履行 的意识习惯, 内化为自身主动的学习常态之中, 学习知识 技能, 逐步适应社会的发展。

\section{2. 从建设实践层面构建终身教育体系}

终身教育理念自从导入安顺并得到广泛传播以来, 终 身教育的发展也伴随着政府的推进和计算机教育的发展, 进一步朝着制度化和多元化的方向迈进。具体到实践层面 构建终身教育体系, 所涉及的问题很多, 但总的来说, 这 是一项全局性、综合性的系统工程, 与包括高等学校在内 的社会各个领域都密切相关, 因此, 这种新体系的构建是 社会整体教育的统合。

\section{2. 1. 建立终身教育的保障机制}

在终身教育还没有被社会普遍认识的现阶段, 安顺市 想要实现计算机教育的大众化, 教育质量的大幅度提高, 就要发挥政府的宏观管理作用。在政策层面上为正规教育、 非正规教育、非正式教育间的协调和沟通提供切合实际的 指导, 教育所需经费的合理投入 [5], 在法律法规层面上, 尝试在条件具备的县区, 建立适应当地教育发展的地方性 法规, 逐步形成一套适合安顺市实际的、可操作的规范体 系, 以法律手段保障终身教育的有效开展, 促进学习者自 主自愿学习, 营造终身教育体系健康发展的条件和氛围。

\section{2.2. 建立弹性开放的教育体制}

在国家建立“课程超市，学分银行”条件下，树立全方 位开放的教育观念, 逐步建立和完善有利于终身教育的体 制, 实现学校向社会开放, 并把计算机教育纳入终身教育 体系, 发挥正规教育、非正规教育和非正式教育等多种功 能, 实现对学习成果进行学分认证和积累[6]。在教育类型 上, 沟通职业教育、成人教育、远程教育和高等教育, 为 每一个社会成员提供学习机会, 合理配置资源, 促进计算 机教育成果的社会化和相互之间的衔接和互认; 在教育层 次上, 打破传统教育封闭的壁垒, 以远程开放教育和网络 教育为依托, 充分利用各种教育模式, 形成容纳家庭教育 和社会教育为基础的开放式教育系统, 实现学习者在网络 平台上自主学习计算机知识, 打通互认和转换机制[7], 促 进教育体制的弹性化、多元化和全方位一体化。

因此，建立开放的终身教育体制，对安顺市普及计算 机教育具有非常重要的作用, 不但有助于个体自主学习意 识和能力的提升, 有助于各类组织或团体的教育需求和潜 能的开发, 而且是计算机教育存在、延续、发展的基础和 条件, 也是决定教育活动的根本动力。

\subsection{3. 创设有利于终身教育体系构建的激励机制}

科学、合理的激励机制有利于终身教育体系的构建, 促进社会成员的综合发展。终身教育包括社会所有成员, 强调为一切人的教育, 在人的一生的各个阶段都能根据个 
人要求获取需要的知识, 实现顺利学的教育环境。安顺市 为社会成员开展终身教育, 教育经费是构建体系的经济基 础, 仅仅依靠政府的重视和投入, 将孤掌难鸣, 还必须充 分调动社会各种力量, 包括各种企业和社会团体, 建立相 应的激励机制, 鼓励有条件的单位、组织和个人积极投资, 逐步完善奖惩制度。因此, 在安顺市构建终身教育体系, 普及计算机教育, 需要建立健全各项监督制度, 确立区县、 乡镇为单位在终身教育投入中所承担的份额, 科学利用经 费，建设“全员、全程、全方位学习”的计算机课程资源 平台, 建立学习档案, 以学分或技能评价学习的效果, 从 而激励社会成员参与到终身教育建设中来。对于社会成员 通过终身教育获得的学分或技能, 作为申请学历教育的资 格或者工作升职的条件, 能够大大激发人们学习的积极性。 此外, 还要创新思维和学习方式, 领导并带动全员到实践 工作中、具体工作中发现问题, 解决问题, 并对自觉进行 终身教育的个人或团体给予表彰奖励, 鼓励“有点到面”开 展学习活动 $[8]$ 。

\section{4. 促进计算机教育大众化发展的措施}

\section{1. 开展终身教育系列活动}

根据安顺各县区特色开展计算机技能比赛活动, 培养 学习计算机技能的意识, 营造有利于社会成员健康学习的 环境。具体开展以文字录入, 图文混排, 电子表格和幻灯 片制作项目的比赛, 着重加强计算机基础应用在比赛活动 中的交流; 以地方特色开展网站设计、LOGO制作、 acd 制图等比赛项目, 并对设计成果进行答辩, 锻炼计算机软 件应用能力。举办计算机技能比赛, 以政府为主导, 社会 机构或成员也可以自发组织, 面对全体社会成员开展, 一 方面宣传了安顺市的特色文化, 增强了参与意识, 活跃了 氛围; 另一方面对健全终身教育形式, 完善终身教育制度, 培养终身学习的习惯, 创新终身教育方式都具有积极的推 动作用。

\section{2. 搭建大众化学习平台}

\subsection{1. 依托高等教育机构, 搭建计算机技能学习平台}

依托安顺市政府提供的丰富资源, 发挥高等教育机构 的主导作用, 搭建计算机技能平台, 优化设计计算机资源 [9]。如可以依托安顺学院, 搭建计算机技能学习平台, 各 县区设立管理机构, 搭建一个高质量、大容量、系统化的 计算机“网络课堂”, 从而形成获取知识、开阔视野、提高 素质、增长才干的一个大众化学习的交流基地; 依托安顺 市广播电视大学建立的网络学习平台, 提供全国高等学校 丰富的计算机学习资源和全方位的支持服务, 满足不同层 次学员的需求; 依据安顺职业技术学院, 建成连接市、县、 乡、村的“数字乡村”平台, 向社会成员及时发放计算机学 习材料, 提供支撑技术, 传递教学视频, 促进计算机技能 水平的提高。

\subsection{2. 依托基层组织, 建立 “计算机学习港”}

可尝试在乡镇、社区、企业和行业等基层组织建立“计 算机学习港”, 就像建立现实世界中的教育超市连锁店一
样为终身学习社会提供满足适合学习需要的资源和支持 服务, 方便社会成员随时随地的学习 [10]。建设该学习港 应充分考虑社会各类人群的需求, 按市场机制组织教学和 提供学习资源, 将资源和服务通过网络传送给社会成员, 形成“数字化资源超市”, 使学习者得到及时的和低成本的 服务。

\section{3. 建立终身教育场所}

通过建设西秀区旧州镇终身教育示范点, 以点带面, 适时推广, 推动安顺全市终身教育发展。安顺市所辖旧州 是国家级历史文化名镇, 具有得天独厚的自然生态条件。 目前, 在教育部门的大力支持下, 本人已设计开发计算机 技能学习平台, 筹备在旧州镇建立终身教育场所, 由旧州 镇政府和安顺学院电子信息与工程学院共同负责管理。该 场所将聘请安顺学院计算机教师为辖区内居民免费开展 计算机技能培训等终身学习活动。

通过建立旧州镇终身教育示范点, 拓展了计算机服务 社会发展的领域和手段, 极大地满足了社会成员多样化的 学习需求, 完善了终身教育体系。为此, 教育部门还需要 继续开拓思路, 把建立教育场所纳入教育发展规划当中, 在全市进行推广。同时, 要通过各种渠道进行宣传, 使社 会成员切实树立终身教育的理念, 充分认识到发展终身教 育的重要性, 增强他们的参与意识, 更重要的是让他们真 正感受到, 终身教育是社会变革和自身可持续发展的需要。

\section{5. 结论}

发展终身教育, 任重道远。从安顺市当前的经济社会 发展来看, 在全市构建终身教育体系, 大力开展计算机教 育, 面临着机遇和挑战。在这个过程中, 可以有意识地采 取分区规划的方式分步推进。在经济实力较强、产业结构 发展较快、居民收入较高的区县设立示范点, 加强法律监 督、政策扶持和教育资源投入，充分调动政府、社会团体 和个人等共同参与建设终身教育体系的积极性, 努力寻求 大众化教育的新路子。通过允许示范点在发展终身教育事 业方面先行先试的措施, 有效发挥对其他地区的示范带动 作用, 积极稳妥地推进终身教育, 最终实现终身教育体系 的完善, 计算机大众化教育的普及。

\section{致谢}

本文为贵州省科技厅、安顺市政府及安顺学院三方联 合基金重点项目《计算机技能培训平台的设计研究》

（QKHLHZ[2015]）的阶段性成果之一。

\section{参考文献}

[1] 吴遵民, 谢海燕. 当代终身学习概念的本质特征及其理论 发展的国际动向 [J]. 继续教育研究, 2004(3):031-036。

[2] 王新元. 探讨终身教育思想 构建终身教育体系 [J]. 兰州学 刊, 2005(6): 0340-0341。 
[3] 安顺市教育局．2015年教育年鉴（R）．安顺：2016。

[4] 叶红英. 论终身教育体系的构建 [J]. 继续教育研究, 2004,(3)。

[5] 冯晓玲. 深化教育体制改革, 构建终身教育体系 $[\mathrm{J}]$. 井冈 山学院学报, 2008(29):0132-0135。

[6] 问景真. 国家开放大学持续推进学分银行建设 明确认证标 准三种模式 $[\mathrm{EB} / 0 \mathrm{I}]$,

http://ou.china.com.cn/2015-06/10/content_7978178.htm
[7] 王丽娜, 郭青春等. 开放教育与网络教育学分互认的现状、 问题与对策 $[\mathrm{J}$. 天津电大学报，2015(1):0021-0025。

[8] 陈乃林. 进一步推进社区教育发展 为基本形成学习型社会 夯实基础[J]. 职教论坛，2016,(21):74-77。

[9]叶翔. 我国当前终身教育体系构建中存在的主要问题及对 策俄探讨 $[D]$. 湖南师范大学, 2003。

[10] 陈德人, 张尧学. 数字化学习港: 构建面向终身学习的学 习型社会 $[\mathrm{M}]$. 浙江: 浙江大学出版社, 2009。 